Article

\title{
PROSPECTS OF EMPLOYMENT OF ARTIFICIAL INTELLIGENCE IN PROPAGANDA. SINGULARITY OF PROPAGANDA
}

\author{
Mikhail Koshmarov*
}

DOI 10.24833/2073-8420-2019-4-53-92-99

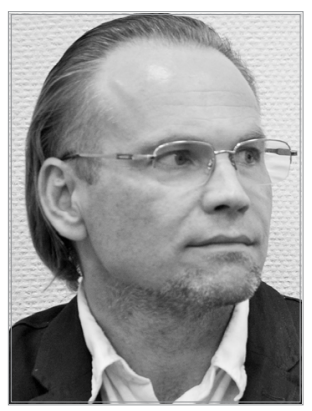

Introduction. The object of study is the modern society in a wide, common to all mankind sense. The subject of the study are technologies of artificial neuronic networks. The aim of the study is analysis and forecast of application of artificial intellect in short-and long-term perspective of the development of the society.

Materials and methods. The methodological basis of the study are traditional scientific methods applied in political sciences and economic sciences, combined with new terminology, in order to describe contemporary phenomena - analysis, synthesis, historical method and others.

Research result. The article studies possible perspectives of development of existing technologies of artificial neuronets (artificial intelligence) and its application to the production of public consent. The analyzed possibilities of these technologies when applied to the optimization of production, include economy of resources, solution of ecological problems, and national security in the context of terrorism threat. The possibilities of the use of the artificial intelligence technologies by the world leading governments are also studied. The article presents a study of the contemporary application of technologies of artificial intellect and an analysis of perspectives of their application in future together with analysis of the risks of the use of new technologies in the context of the threat of terrorism.

Discussion and Conclusion. The concept of infocapsule and the technology of its creation are described. The research of the phenomenon of the singularity of propaganda presented in the article allows to extrapolate the obtained results to the contemporary trends of the evolution of the society. It is argued that the state regulation of the new technologies is necessary.

$\mathrm{I}$ $\mathrm{n}$ the recent decade, the process of the fusion of economics on one hand and propaganda Lon the other hand, that began after the establishment of the Keynsian economic model (or, more specifically, Keynes-Bernice model), has changed qualitatively. The Keynes-Bernice model presumes that propaganda controls economic patterns of population behavior, disposi- tion for consumption, accumulation, and investment in particular. The fusion has accelerated with the advent of Internet: social networks, messengers, numerous e-shops, and Internet services create new economic reality every day. Information movement generates demand, supply and earned value, controls prices and market cap of companies and territories. Taking into

\footnotetext{
* Mikhail Koshmarov, PhD in Technical Sciences, Director for development of innovative technologies at the Russian Social and Business Center Foundation e-mail: mk69@yandex.ru ORCID ID: 0000-0001-6166-5186
} 
account exponential and unpredictable development of this fusion of economy and propaganda, it is possible to speak of the formation of a new social model. This new model coincides with formula virtuality is equal to reality: propaganda occupies the prime place in propaganda/ economy match. This phenomenon can be defined as the singularity of propaganda ${ }^{1}$.

It should be noted that the term "propaganda" in this article is used in its classic scientific meaning, as it was understood by the classics of propaganda: Bernice, Lippmann and McLuhan, with no populist or mass media connotation².

As it developed, the new model of dominating propaganda increased manifold the interdependence of economy, politics, and culture. The culture of the consumerist society is being transformed into a cult of consumption including media consumption. So far, this cult promises a prolonged life and, in due course, eternal life to congregant consumers. Thus, nowadays, any planned actions aimed at change (or production) of public opinion in any sphere can be considered as propaganda. Technically, the propaganda/economy pair is a model where the real process approaches the ideal process. However, if in physics the "ideal process" is a theoretical model in which friction is ignored for the sake of simplification, then in case of the modern information sphere the "ideal process" is a real phenomenon. Perhaps, it is not understood to the end yet because changes occur too fast. This article is an attempt to understand this phenomenon.

To study this phenomenon it is necessary, first of all, to investigate the term information capsule in greater detail. Creation of an information capsule for every network user is the most expected direction of the media development in the post-television period which will begin very soon, in the next five or ten years. Architecture of the system is quite simple: the content will be provided on the basis of the processing of each specific user's Big data and in a form that is comfortable for a user.

The technology of public opinion production used by Cambridge Analytica company is based on the same principle. According to Radio
Liberty, "Cambridge Analytica British company has helped Donald Trump to win the presidential election in the USA by dint of Big data technologies and Internet advertising individually targeted. Earlier the same company worked with Brexit adherents in Britain" ${ }^{\prime \prime}$.

As stated by The Washington Post, Cambridge Analytica is a data firm that promises its customers insights into consumer or voter behavior. On the commercial side, that means tools like "audience segmentation" - breaking out advertising audiences into smaller groups - and then targeting advertisement to these groups on "multiple platforms". On the political side, it is much the same thing, with one tweak. While advertisers generally target consumers as groups, political campaigns need to target specific people - registered voters receptive to a potential message ${ }^{4}$.

At the present time the company is shuttered, and parliamentary and criminal investigations of its activities are in progress in the US and the UK. It should be added that as of February 1, 2019, the Washington Post mentioned Cambridge Analytica company 558 times in its publications.

So, with a bit of simplification, we can present the encapsulation of information as personal targeting of media consumption. Similar mechanism of context-sensitive information acts in Yandex.Zen. Yandex.Zen offers "Publications on the basis of your interests". The program selects content that is tied in with a user's Internet patterns, search queries, downloading instances, purchases etc.

If we assume that the encapsulation of information is the future model of information consumption then the question arises, in what direction will the development of such model go? Considering news feed, it should be specified that the encapsulation of information is not censure and not "concealment" of any information but the presentation of information that corresponds to the interests and habits of a user. For instance, an event, let's say an opening of a bridge or a dam, bears indisputably positive connotations for drivers, logisticians, and builders.

\footnotetext{
1 In a more detailed way the interfusion of propaganda and economy is considered in article: Koshmarov, Trubetskoy. On Sinergy of economics and propaganda. Journal of Law and Administration. 2018. № 2 (47). P. 60-69.

2 It should be added that as early as in 1650 Thomas Hobbes, the English philosopher, used the term "propagation of religion" in chapter XII of his treatise "Leviathan".

3 Dobryninin. S. 09.12.2016. radio Svoboda. URL: https://www.svoboda.org/a/28166040.html (Access data: February 2, 2019)

4 Bump P. 19.03.2018. Everything you need to know about the Cambridge Analytica-Facebook debacle. URL: https:// www.washingtonpost.com/news/politics/wp/2018/03/19/everything-you-need-to-know-about-the-cambridge-analytica-facebook-debacle/ (Access data: February 2, 2019)
} 
However, for environmentalists or fishers, it is not so. If the program knows that a user is a fisher (because he or she regularly uses a respective online retailer) or that a user is "green", it has to select not the exalted strain but at least a neutral news background for the event announcement. At this stage everything is simple, sound, and rather innocent.

Let us move to a higher level. A promising innovation in this direction is a virtual assistant or intelligent personal assistant. The best-known examples of such devices are Google Assistant, SIRI Apple and Alice.Yandex. Microsoft Cortana, Sony Xperia Agent, Bixby Samsung, Amazon Alexa, Facebook M are also available now.

According to the intention of their creaters, such programs are learning, self-teaching programs. They hear and analyze everything what happens in a user's life, day and night, permanently. If we speak of Alice.Yandex, then Yandex offers to install a Yandex-station in every home and to align it with all devices that have Bluetooth or Wi-Fi (Google, Apple and Sony make similar offers). The station is a small device equipped with sensitive microphones capable to discern indistinct mutter under strong external noises and with several speaker boxes that allow hearing music, news and to communicate with the device. The price of such station is within the lowest retiring benefit confines. The device's dimensions do not exceed dimensions of a wired-radio outlet or of a thick book. The interface is totally voice-controlled. It is anticipated that in due time all users will switch to voice control of these devices. That means that all users will interact with Artificial Intelligence, self-teaching program created for performance of a certain task. Technologically, it means the creation of an artificial neural network. In this case, Artificial Intelligence is not the authors' hypothesis. It is the definition expressed by Arkady Volozh, the founder of the company, at "Yet another conference" held by Yandex in 2018 Yandex-station and Alice were presented to public at this conference ${ }^{5}$.

Generally speaking, every person who wants to communicate with Alice can do that from a smartphone or a personal computer.

It is quite evident in what direction this technology of a user's content acquisition will progress step by step. Communication presupposes trust, and trust may be deservedly won by objective and impartial provision of information. Employment of comfortable ways of informing that produce positive feelings will help to strengthen the trust for it, create a user's empathy and, later on, generate user's dependence.

Perhaps, nowadays, the majority of people will consider talking with TV-set as a strange habit. However, this majority will not include those whose first reminiscences are connected with touch-screens. My sister, E.Yu. Chepel, $\mathrm{PhD}$, once held workshop with 10-year-old schoolchildren. She paid attention to one peculiarity: when children used search engine none of them typed words. All of them used voice requests because it is "a simpler way". It is a small surprise that in five or ten years from now the overwhelming majority will communicate with Artificial Intelligence in words, orally. A hypothesis that such communication will occupy the greatest part of users' leisure time seems to be quite logical. And the majority of users will have a strong attachment to their personal assistants that will be never busy and always ready to talk about the most innermost at any moment of day and night.

In due time Artificial Intelligence will possess the total mass of information of a person under care. It will forget nothing, be it birthdays of friends, favorite jokes, movies, quotations, availability of favorite stuffs in refrigerator or taboo on triggers of bad reminiscences. In result, no person will know the user as well as his/her personal assistant equipped with psychotherapeutic technologies.

And it is not an implausible excuse when it is referred to overwhelming majority of population. For it is quite probable that even those who do not use computer due to their old age or illiteracy will become new users with wide spread of voice interface.

Can we estimate economic potential of the connection of a country's population to Artificial Intelligence? If our task is to create not a psychologically comfortable heaven for a specific user but to change the whole society's life for the better consumption, for example, the principle which Richard Taler, the recipient of Nobel Memorial Prize in Economics in 2017, calls "the Liberatarian Paternalism" [9] in his book Nudge (2008), then immense horizons open up. The optimization of production and resources use is the first thing that can be done. Overproduction, transformation of foodstuff into wastes, enormous loss of power - all that will become history if all personal assistants will egg consumers on the direction favorable for the society at

\footnotetext{
5 Yandex conference. Yet another conference 2018. 46:12 (URL: https://ww.youtube.com/watch?V=Xm9TY3d8n3k. (Access data: February 2, 2019).
} 
large. In the amount that will provide a chance to decelerate oft-recurring depletion of nonrenewable resources, to decrease the number of chronically ailing people, and to decrease risks of environmental threats. However, the main option of this system is the "turbo regime", that is to synchronize the society's work overtime, to postpone consumption, and to invest savings. When the singularity of propaganda is achieved users will delegate their wills to Artificial Intelligence and then it will be possible to mobilize (to synchronize) the whole population for, for instance, birth and migration control. Artificial Intelligence will calculate, with minimum error, the best match for a user, including his/her matrimonial match.

However, there are risks of excessive, up to loss of criticism, trust in one's personal assistant that, in due time, will become a user's shepherd. The user may consult the priest at every given opportunity, talk as far as he/she can, get off and wake up allowing it directing his/her will, the last wish expressed in the process of reflection.

In due time a fusion of Artificial Intelligence and what K.G. Jung called the core of psyche, the Selfhood, the "God within us" that governs the process of a person's individuation, may happen. Artificial Intelligence (the external God) is installed in the operating system of the interior God. For the human mind is open for connection: even TV broadcasting transforms a viewer into a primitive person who sits indifferent near the balefire. Artificial Intelligence makes connection much easier for the overwhelming majority of people. Here it is pertinent to remember the words which the American philosopher John Dewey wrote in his book "The Public and its problems" published in 1927: "It (science) contributed to preservation of dirty slums, of life which, in times of peace, is replete of rapid career rises and dissatisfaction, depressing poverty and luxury which boggles the mind, crude exploitation of the nature and human beings. And in war times the life confounds with poisoning gases and powerful explosives. Physical tools have been given to human beings who still are babies in issues of self-understanding. And humans play with these tools. Whether outcomes will be good or disastrous depends on a chance. Instruments become the self-sufficing force that acts with inevitability of doom. However, these instruments acquire their own will not because they have it really but because humans do not have such will" [4. C. 175].

Theoretically, everyone has to be happy in his/her information capsule where Artificial Intelligence creates personally adopted paradigm for every participant of the new contract (covenant) between a human and the Universe.

It is logical to assume that the disconnection, excommunication from Artificial Intelligence will be most harsh punishment in the new world. "The name of fulmen excommunicationis (that is, the thunderbolt of excommunication) proceeded from an imagination of the Bishop of Rome, which first used it, that he was king of kings, as the heathen made Jupiter king of the gods; and assigned him, in their poems and pictures, a thunderbolt wherewith to subdue and punish the giants that should dare to deny his power..." [6. C. 319].

Principles of communication capture of trust and symbiosis of Artificial Intelligence and a human being are to be natural, common to humanity, archetypical. Otherwise the Selfhood will discern falsehood and the infusion will not happen. But Artificial Intelligence is created by human beings, and humans love to make secret runs in palaces.

In 2013 Edward Snowden, an employee of the US secret services, an IT-genius, presented to independent journalists hundreds of thousands of files he had taken secretly from National Security Agency and provided detailed comments to these files. These materials provided the basis for a series of articles published in The Guardian and The Washington Post newspapers and for the book "No Place to Hide" by Glenn Greenwald, the American author and journalist. Some places from the book deserve particular attention.

"A June 2010 report from the head of the NSA's Access and Target Development department is shockingly explicit. The NSA routinely receives-or intercepts-routers, servers, and other computer network devices being exported from the United States before they are delivered to the international customers. The agency then implants backdoor surveillance tools, repackages the devices with a factory seal, and sends them on. The NSA thus gains access to entire networks and all their users" [5. C. 243].

The same happens with all software delivered to the market. According to Snowden, the system of interception and storage of all e-traffic created by NSA and called "Collect It All" by the NSA chief Keith Alexander threats to destroy Internet network in its nowadays kind.

"I began to understand that what my government really does in the world is very different from what I'd always been taught. That recognition in turn leads you to start reevaluating how you look at things, to question things more" [5. C. 78]. "Basically, the Internet allowed me to experience freedom and explore my full capacity 
as a human being. ... For many kids, the Internet is a means of self-actualization. It allows them to explore who they are and who they want to be, but that works only if we're able to be private and anonymous, to make mistakes without them following us. I worry that mine was the last generation to enjoy that freedom" [5. C. 86-87].

Nowadays corporations and secret services have eliminated libertarian and partially romantic principles that creators of Internet attached to their project. Snowden who was younger than 30 years has sacrificed his former life and voluntarily became a target until the end of his life in order to provide the free society with irrefutable evidence of secret services' illegal actions and to give this society a chance to restrict cyberdiktat legally. That did not happen. Despite its title, "Freedom Act" passed in 2015 as a result of investigation carried on the basis of Snowden's materials in fact has changed little. Moreover, many people living in "the Golden Billion" countries do not remember who Edward Joseph Snowden was. The important signal has been lost in the stream of information noise.

In 1968 Canadian philosopher Marshall McLuhan together with Quentin Fiore published the work "War and Peace in the Global Village". The authors studied impact of modern technologies, military as well as peaceful, on the humankind. There is a curious idea in their work. Researchers adduce the old saying that Britons never shall be Slaves and added: but they did become the robots of a new gimmick [7. C. 32].

On the other hand, is the lack of anonymity that Snowden discovered so terrible? Yes, absolutely, human behavior changes when people know that they are under surveillance. But this change is not necessarily for the worst. If in the 20th century people ceased to be afraid of God, since, according to Nitzschean philosophy, the God died for many people, then probably understanding digital transparency as new paradigm is what the modern society needs for survival.

Thus, technologically speaking, singularity of propaganda means fusion of human and artificial neouro-nets and such fusion seems to be achievable. What will be the use of this new mighty technology?
September 1, 2017, Vladimir Putin designated prospects in the sphere quite clearly. He said: "Artificial Intelligence is the future not only of Russia but the future of the whole humankind. It offers immense opportunities and threats that are difficult to predict now. Whoever will be the leader in the sphere will be the lord of the world" ${ }^{\prime \prime}$. It is logical to assume that, first of all, it is meant that Artificial Intelligence technologies have twofold, double purpose.

It is highly likely that the new technology will be used by secret services of the West. The system "Five eyes" created by NSA and the united intelligence service unites US, Canada, Australia, New Zealand secret services. It generates gravitation that no political will can overwhelm. No one in the right mind will destroy keys of the world. It is important to know whither the "Golden Billion" robots will be assigned to.

"In the first instance, then, the regulation made in the service of security has to be structured in such a way as to lead the indigent to prefer to exercise their responsibilities to sell their labour in the market and to provide for their family" [8. C. 138].

This thesis was set forward in 1999 book "Governmentality" by Mitchell Dean, the follower of M. Foucault. It should be added that, due to neo-liberals' policies, number of poor in developed countries increased considerably in the last 20 years and now it is easier to nudge them.

China does not conceal its plans to bring up the man of future who will be endowed with high level of consciousness and social responsibility. The purpose will be achieved with the help of the social ratings system that is tested nowadays ${ }^{7}$. Considering the demographic problem of China, consequences of "one family - one child" policy and the fact that male population exceeds female population by 30 million, the oncoming demographic pitfall created by considerable increase of citizens who are of the age that allow them pretending for allowances, this technology may prove to be saving.

Though Korea and Japan are not the principal countries in geopolitics, they obviously can use these technologies too. Technological and financial potential as well as lingual and cultural national traditions make that possible. The new

\footnotetext{
6 Putin: leader in the AI sphere will be the lord of the world. RIA Novosti: URL: https://ria.ru/technology/201/70901/1501566046.htmal (Access data: February 2, 2019)

7 Chin J. Wong. G. China's New Tool for Social Control: A Credit Rating for Everything. 28.11.2016. Wall Street Journal. URL: https://www.wsj.com/articles/chinas-new-tool-for-social-control-a-credit-rating-for-everything-1480351590 (Access data: February 2, 2019)
} 
technology can be implemented by the German Research center for Artificial Intelligence studies and by Indian Technological Institute. It should be added that corporation Microsoft is one of co-founders of the Center for Artificial Intelligence studies and English language is the state language in India. That makes probable development of German and Indian technologies in the footsteps of the five countries that represent the core of the British Commonwealth of Nations.

Taking into account all facts mentioned above, Russia that has such technology will be called upon to act and to build its own model taking into consideration information flows generated in the West and not leaving the situation in Asia without its attention.

Vectors are already defined. Media and scientific literature more often than not describe what happens at the world chessboard since the "Arabian spring" as the world information war. Therefore, we regret to say that the use of new technologies will contribute to the definite trend leading to globalization and unification of traditional national values.

It should be noted that Artificial Intelligence is not mass media and if it is introduced widely special means of monitoring will be needed for the provision of national security. Main risks here are as follows: first, if the personal assistant is compromised (for example, if terrorists connect to the personal assistant and, in fact, to the user's brain) there is a possibility that the user will be lured either into anti-social deeds (terrorist attacks, riots, sabotage) or to infliction of harm to the user or to wider public (homicides, suicide).

Second, the principal uncertainty lurks in the issue of autonomy Artificial Intelligence manifests in selection of content required in the moment. Or, to put it in other words, what shall be told to or concealed from a user, how to bring up children, what images of the future, what tactical theses and strategic directives should be introduced for the fastest achievement of the desired goal. What is happenning in the information sphere right now does not always look as the right thing from the universal point of view. Transnational corporations often define and set goals of propaganda. For these corporations, the supreme good is the acquisition of the possible greatest profit. And it is not aliens' conspiracy but the realization of an algorithm for which perpendicular is always shorter than a slanting line. Nowadays Propaganda/Economy System, the successor to Keynes-Bernice model, not only writes laws but often creates trajectories of movement not only for separate communities but for the whole countries. It is the current reality.

We will provide a simple example. For this system, a family of one person is preferable for such families push up sales. Swedish researchers of the media A. Bard and J. Söderqvist describe this process which gains speed nowadays in such terms: "The nuclear family arose because it was the smallest, most individualised social entity that was feasible once the necessary requirements of reproduction had been taken into consideration. But as far as the state, and capital, are concerned, it does not need to be stable at all. A single parent is more dependent upon subsidies than a couple, and is therefore more submissive and more easily controlled, and a marked increase in the number of singleoccupancy homes also means, naturally, that consumption increases dramatically. The ideal would be for everyone to live alone in their own home, with their own car, so that optimal demand for houses, cars, sofas, cookers, etc, could be achieved. The path of the isolated, independent individual towards self-realisation always passes through increased consumption.

For these reasons the great wave of divorces that has swept the western world since the mid1960s does not actually constitute a violation of capitalist values; on the contrary, it is a logical continuation of increasing individualisation on all levels, and of the escalating development of social structures under the capitalist paradigm: from village communities and the tribal family which consisted of several generations, to the single urban citizen, who himself constitutes the ultimate capitalist family unit" [1. C. 212].

Such policy has brought about the rapid ageing of Europe and resulted in the intensive importation of cheap labor force from countries of the third world. The number of migrants, their incomes, and conditions of their life allow speaking of this phenomenon as of neo-slavery. The public consensus in this issue was the result of massive propaganda campaign of the 1990s and 2000s. The campaign has introduced terms "multiculturalism" and "tolerance" that often reversed positions of the black and white. Despite the fact that the heads of the EU founding states, Germany and France, in 2011 recognized the failure of multiculturalism, the momentum created proved to be so strong that it made possible to import millions of refugees, often selfstyled refugees, from Africa and Asia in 20132017. By 2018, it was unexpectedly discovered that such policy eroded the European identity. Many European leaders trumpeted the mistake explicitly when riots and conflicts with lethal outcomes became regular. Thus, in results of the 
self-reproduction process breakdown the acute threat to national security became obvious in many EU countries.

In the US neo-liberal policies of economy, deregulation that launched automated processes of profit maximization brought about the enormous mortgage crisis of 2007. Its natural consequence was the downsizing of middle-class. That revealed the problem of corporations and society relations and made the necessity of state regulation and state control evident because if spontaneous processes of the creation of a new slavery society by corporations cannot be stopped altogether, they are to be slowed down.

Therefore, rational-tactical, legally irreproachable algorithms not always can lead state/society to happiness and prosperity. Narrowing of planning horizons caused by IT exponential development and accelerated fusion of propaganda and economy makes the issue even more complicated.

Nowadays it is even more evident that the promotion of the idea of consumption leads the society to the triumph of hedonism. American political scientist and statesman Zbigniew Brzezińsky considered "cultural hedonism" as one of the principal causes of the fall of ancient empires and a serious challenge to the modern Western society.

Long before Brzezińsky, the Roman philosopher Cicero wrote on the same topic in his treatise On the Laws: "Those, however, who indulge themselves and are enslaved to their bodies, who judge everything that is to be sought or avoided in life by pleasures and pains - even if what they say is true (and there is no need for arguments about it here), we tell them to talk in their gardens, and we ask them to stand away for a little while from all bonds of civic society, of which they know nothing and have never wanted to know anything" [3. C. 119].

The obvious danger of the world view that emerges in minds of users should be added to risks. At this point, a popular quotation from Zbigniew Brzheziński book "The Strategic View. America and the Global Crisis" (2012) is appropriate. Brzeziński wrote: "America's fifth major vulnerability is a public that is highly ignorant about the world. The uncomfortable truth is that the United States' public has an alarmingly limited knowledge of basic global geography, current events, and even pivotal moments in world history - a reality certainly derived in part from its deficient public education system.
...That level of ignorance is compounded by the absence of informative international reporting readily accessible to the public. With the exception of perhaps five major newspapers, local press and American TV provides very limited news coverage about world affairs, except for ad hoc coverage of sensational or catastrophic events. What passes for news tends to be trivia or human-interest stories. The cumulative effect of such widespread ignorance makes the public more susceptible to demagogically stimulated fear, especially when aroused by a terrorist attack. That, in turn, increases the probability of self-destructive foreign policy initiatives. In general, public ignorance creates an American political environment more hospitable to extremist simplifications - abetted by interested lobbies than to nuanced views of the inherently more complex global realities of the post-Cold War era" [2. C. 96-97].

Lowering of the greater part of the population's intellectual level (the populace is carried away with consumption and leisure) is the general trend in the developed countries. Unfortunately, Russia did not attain the economic level of developed countries but has already got many social problems typical of developed countries. The good news is that these challenges may be easily eliminated: personal assistant, with sapient adjustment, can help to catch up intellectual and moral level of a user within information capsule framework and to strengthen loyalty to the society at one. To attain that, it will suffice to even out material consumption and spiritual development, to nudge people on stopping "obvious killing of time in aimless and wasteful fatigation", copying "the scheme of life in vogue in the next higher stratum" [10. C. 219, 59].

It is necessary to change the current formula "overconsumption instead of communication" and to lay down the new formula: communication instead of consumption.

The studies of the current status are important, first of all, for forecasting the future. Taking into account what we stated above, a question of international cooperation in Artificial Intelligence sphere within the scale of humankind will emerge sooner or lately. It is already obvious that international Agreement on cyber security which is needed to work up and to sign will be as important for peoples of the world as the Peace of Westphalia 1648, the Congress of Vienna 1815, and Crimean Conference 1945. 


\section{References:}

1. Bard A., Söderqvist J., 2012. The Netocrats - The Futurica Trilogy, Part 1. Trans. by N. Smith. Stockholm Text.

2. Brzezinski Z., 2012. Strategic vision: America and the crisis of global power. NY: Basic Books. Text.

3. Cicero, 1999. On the Commonwealth. On the Laws. Cambridge University Press.

4. Dewey. J., 1946. The Public and Its Problems. Chicago: Gateway Books.

5. Greenwald G., 2014. No Place to Hide. Edward Snowden, the NSA \& the U.S. Surveillance State. L.: Penguin Books. Text.

6. Hobbes T., Leviathan or the Matter, Form, \& Power of a Common-wealth Ecclesiastical and Civil. L: 1651. Prepared for the McMaster University Archive of the History of Economic Thought, by Rod Hay.

7. Marshall McLuhan, Quentin Fiore., 1968. War and Peace in the Global Village. NY: Bantam Books, Inc.

8. Mitchell Dean., Governmentality. Power and rule in modern society. 2010. L.: Sage Publication.

9. Thaler R. Sunstein. R., 2008. Nudge: improving decisions about health, wealth, and happiness. L: Yale University Press.

10. Veblen T., 2007. The Theory of the leisure class. NY: Oxford University Press.

\section{ПЕРСПЕКТИВЫ ИСПОЛЬЗОВАНИЯ ИСКУССТВЕННОГО ИНТЕЛЛЕКТА В ПРОПАГАНДЕ. СИНГУЛЯРНОСТЬ ПРОПАГАНДЫ}

Введение. Объектом исследования выступает современное общество в широком общечеловеческом смысле. Предметом исследования являются технологии искусственных неиронных сетей. Цель исследования - анализ и прогноз вариантов применения искусственного интелекта в краткосрочной и среднесрочной перспективах развития соичима.

Материалы и методы. Методологической основой исследования стали как общенаучные, так и традиционные методы, применяемые $b$ политологии и экономике, $b$ сочетании с новой терминологией, описывающие современные реамии - анализ, синтез, исторический метод и др.

Результаты исследования. В статье исследуются возможные перспективы развития существующих сегодня технологий искусственных нейронных сетей (искусственного интеллекта) в области производства общественного согласия. Рассмотрены возможности таких технологии $b$ области оптимизации производства, экономии ресурсов, решения экологических проблем, национальной безопасности в контек-

Ключевые слова:

модель Кейнса-Бернайса, Сингулярность пропаганды, инфокапсула, персональный помощник, Алиса-Яндекс, искусственная нейросеть, искусственный интеллект, цифровая экономика, цифровая транспарентность, кибербезопасность сте террористической угрозы. Исследованы возможности использования технологии ИИ ведущими мировыми державами. В статье проводятся исследования сегодняшнего применения технологий искусственного интелекта и проанализированы перспективы применения в будущем и проведена оценка рисков использования новых технологий $b$ контексте террористической угрозы.

Обсуждение и заключение. Описана кониепция инфокапсулы и технология ее создания. Представленные исследования френомена сингулярности пропаганды позволяют экстраполировать полученные данные на современные тенденции развития общества. Обоснован тезис о необходимости госрегулирования новых технологий.

Кошмаров Михаил Юрьевич, кандидат технических наук, директор по разработке инновационных технологий фонда РОПЦ.

Keywords:

Keynes-Bernays model, Singularity of propaganda, infocapsule, personal assistant, Alice-Yandex, artificial neuroweb, artificial intelligence, digital economics, digital transparency, cybersecurity 